\title{
Practice Research on Commercial English Specialty Courses System and Professional Standards in Nanjing Institute of Industry Technology - Based on "National Standard of Undergraduate Teaching Quality of Business English Major in Colleges "
}

\author{
Sha Wang \\ Nanjing Institute of Industry Technology, Nanjing, Jiangsu, 210023
}

Keywords: Business English, course content, professional standards, teaching quality national standards

\begin{abstract}
Based on the National Standard of Undergraduate Teaching Quality for Business English Major in Colleges and Universities issued by Ministry of Education in 2015, this paper analyzes the training quality evaluation report of New Graduates of Nanjing Institute of Technology in 2017, And put forward suggestions on how to build a curriculum system based on professional standards, cultivate a solid foundation of English knowledge and can apply for complex and applied business English professionals engaged in international business.
\end{abstract}

\section{Introduction}

"Belt and Road" opened up a new starting point for our international cooperation. This will provide more employment opportunities for business English professionals. However, it also sets higher requirements for the training of business English professionals with the times. Therefore, how to combine the business English professional curriculum system with professional standards closely and combine the talent cultivation with the national standards of teaching quality so as to cultivate business English talents who adapt to the needs of social development becomes the research focus of the current business English major construction.

\section{Business English Teaching Quality Standards}

In 2015, the Ministry of Education promulgated the "National Standard of Undergraduate Teaching Quality in Business English for Institutions of Higher Learning" (hereinafter referred to as "Shang GB"). "Business English Standard" has a clear and thorough interpretation of the definition and professional positioning of business English, business English quality, knowledge and ability requirements, business English professional curriculum system and curriculum construction and business English teaching faculty building.

According to the definition of Business English, "Business English Standard" breaks the recognition that business knowledge is the dominant or knowledge-based English for many years and points out that business English is a special new discourse system formed by interdisciplinary1, Science, business administration, applied economics and other interdisciplinary professional names. Therefore, the "Business English Standard" believes that the professional standards for cultivating business English professionals should be complex and applied talents who have a solid knowledge of English and are able to engage in international business.

According to the characteristics of Business English, Business English Standard specifies five qualities, five abilities and five kinds of knowledge that Business English professionals should possess. Among them, the five types of qualities are: ideological quality, professional quality,

Professional ability, cultural quality and physical and mental qualities; five abilities are: English application ability, intercultural communication ability, business practice ability, speculative and innovative ability and independent learning ability; five kinds of knowledge are: language knowledge, business knowledge, cross Cultural knowledge, humanities and social sciences and 
interdisciplinary knowledge.

In order to achieve the cultivation of the above five qualities, five abilities and five kinds of knowledge, Business English Standard sets up a curriculum system and curriculum from four modules of language, business, intercultural and humanistic accomplishments. Among them, the professional core curriculum to make clear requirements, namely: English knowledge and skills module is $50 \%-60 \%$; business knowledge and skills module is $25 \%-35 \%$; intercultural communication module is $5 \%-10 \%$; Humanistic literacy module is $5 \%-10 \%$. At the same time, "Business English Standard" stipulates that the business English professional curriculum system should include the following five parts: public courses, professional core courses, professional orientation courses, practical links and graduation thesis. Among them: Courses for language skills and skills include: Phonetics, Grammar, Comprehensive English, Business English Audiovisual, Business English Reading, Business English Writing, Business English Translation and other courses; Business Skills and Skills Courses include: Economics, Management Learning, international trade, international marketing, international business law, international business negotiations, e-commerce and other courses, and these business courses can choose bilingual teaching or even English teaching.

\section{Business English Professional Training of Nanjing Institute of Industrial Technology}

Nanjing Institute of Industrial Technology Business English was founded in 1997. In 2003, South Institute of Business English was named Jiangsu Province specialty. In 2009, the professional "Business English" course was awarded the Ministry of Education teach instruction committee excellent course. In 2010, the same course "Business English" course was awarded the Jiangsu province quality courses. In vocational ability training, in order to enable students to achieve "zero distance" with jobs during their studies, the courses offered by the major are mainly divided into English courses and economic management courses. Among them, the courses in English include Business English, Integrated English, English Listening, Oral English, basic English writing, foreign trade English correspondence, business English translation, business English reading, the second foreign language (Japanese / Korean); economic management courses are: international trade practices, trade documents practice, international marketing, Basic accounting, e-commerce, cross-cultural communication courses.

According to Michelle 2017 Nanjing Institute of Vocational Technology graduates training quality evaluation report,

The employment rate of business English majors in South Institute was 96\% in 2015 and that of graduates in 2016 was 93\%. The employment rate of business English graduates in 2016 is 3\% lower than the employment rate of graduates in 2015.

The monthly income of business English graduates is as follows: the monthly income of graduates in 2015 is 3,114 yuan, and the monthly income of graduates in 2016 is 4,082 yuan. 2016 Business English graduates monthly income ratio 2015

Graduates increase 968 yuan. At the same time, the comparison of the monthly income of Business English graduates of South Institute of Technology with similar graduates of similar institutions shows that the monthly income of Business English graduates of South Institute of Technology is 4082 Yuan, and the monthly income of similar graduates of the same kind is 3606 Yuan. South Institute of Business English graduates than similar institutions of similar professional graduates income 376 yuan higher.

In the survey on the correlation between professional and professional degrees of various graduates, the work related professional degree of business English graduates from South Institute was $47 \%$ in 2015, and the correlation between the professional and professional work of graduates in 2016 was 57\%. Compared with the 2015 work and professional relevance increased by 10\%. At the same time, the work and professional relevance of business English graduates from South Institute of Technology was 57\% compared with that of the same kind of colleges and universities in 2016 compared to the same period in 2016. The relevant degree of work and professionalism of business English graduates from South Institute was 57\%. The correlation between the professional 
work and the professional is 59\%. The correlation between the professional and professional degrees of the commercial English graduates of South Institute of Technology is $2 \%$ lower than that of the similar professional graduates of similar institutions.

In the teaching satisfaction survey, the graduates of Business English major in South Institute of Technology in 2016 and 2015 both reached 97\% satisfaction with teaching.

In the survey of the correspondence table of the comprehensive evaluation of the effectiveness of the core professional courses of the major professions, graduates of Business English Major in South Institute of Technology recognized the degree of professionalism as $90 \%$ and the degree of satisfaction as $77 \%$.

According to the above report, we can see that the strengths of 2016 graduates of Business English Major in South Institute are: 1.93\% of the employment rate is higher than the employment average of $91.5 \%$ in the higher vocational colleges nationwide; 2 . Monthly income is more than that of 201, And higher than similar institutions of similar professional graduates 376 yuan per month; 3 graduates of teaching satisfaction (97\%) and professional core curriculum acceptance (90\%) are higher. At the same time, the weaknesses of 2016 graduates of Business English major of South Institute of Technology lie in: 1. Low correlation between work and major and less than $2 \%$ of similar major of similar college; 2 . Comprehensive evaluation of graduates' effectiveness on major core courses Satisfaction (77\%) to be improved.

Third, the "College Business English undergraduate teaching quality of national standards," under the guidance of South College of Business English professional curriculum system and professional standards butt

While defining the mode of training business English professionals, Business English Standards also put forward the requirements for the construction of business English professional hierarchy and classification, that is, colleges and universities should combine their own characteristics, such as geographical location, school orientation, school running tradition, Disciplinary features and advantages, establish a unique talent training objectives for each university, develop individualized talent training programs and curriculum system.

Nanjing Institute of Technology is located in Nanjing, capital of Jiangsu Province, adjacent to economically developed and foreign-funded enterprises in the area of Suzhou, Wuxi and Changzhou. Therefore, it has a unique geographical advantage. In recent years, the school is devoted to cultivating practical talents with "dedicated work and hands". According to the evaluation report on the quality training of graduates of Nanjing Institute of Technology in 2017, 81\% graduates of NITTC stayed in Jiangsu after graduation. Business English majors mainly worked as clerks after graduation and 45\% Of graduates work in small and medium-sized private-owned businesses with fewer than 50 employees.

According to a survey conducted by the Department of Business English of South Institute of Technology to track graduates, there are mainly three jobs for business English graduates: foreign trade clerks (cross-border e-commerce), clerks, and English teachers in educational institutions. Michels 2016 Beijing Institute of Vocational Technology graduates training quality tracking evaluation report shows that business English graduates employment in the main industry for the "international trade." because

This foreign trade clerk (cross-border e-commerce) has always been the main goal of the commercial English talents training at South Institute of Technology. At present, the direction of business English majors and professional curricula are all based on cultivating professional standards of foreign trade business personnel.

With the gradual rise of extra-curricular tutoring classes in recent years, the number of business English graduates serving as English teachers in educational institutions is on the rise. Some students even returned to their hometown, founded their own training institutions, and achieved good results, recognized by parents. Therefore, at the time of the revamping of the Talents Training Program 2018, the SBA will also consider appropriate courses to be taken in connection with this occupational standard to increase the employability of students in language training.

Business English graduates engaged in clerk jobs after graduation is a phenomenon that has 
always existed. However, clerks (secretarial) majors in higher vocational colleges have been at a disadvantage in terms of enrollment and employment. Therefore, the business English major in the professional curriculum system for the clerk occupation standards, only conducted a one-week training, does not intend to expand in the curriculum.

According to the above actual situation, the curriculum system of business English majors in NITTC should closely connect with professional standards of foreign trade clerks and occupational standards of English trainers, embody the qualities, abilities and knowledge required by these two occupations in the curriculum and encourage them through encouraging Students take Social Occupation Certificate exams to enhance students' employment competitiveness in these two occupations.

To develop a curriculum system and professional standards docking - to improve business English graduates work and professional relevance;

Michelle 2017 Nanjing Institute of Vocational Technology graduates training quality tracking evaluation report shows that business English graduates work with less relevant professional, and lower than similar institutions of similar professional, see Figure IV, Figure V. In response to this problem, in addition to combing the training objectives, to determine a clear direction of personnel training, but also according to occupational standards, the need to set up a professional curriculum system.

"Business English standard" pointed out that the business English curriculum system in addition to public courses, dissertations and specialist core courses, but also should include the professional orientation courses and practical aspects of the part. Because different students have different degrees of English, basic English courses exceed 50\% of professional courses. Based on the differences in students' levels, the percentage of basic English courses is increased to consolidate the language foundation of graduates of Business English. For business-oriented professional and cross-cultural courses, to achieve $10-15 \%$ of professional courses, thereby enhancing students' business knowledge and skills in their careers, intercultural business communication skills and humanities.

To carry out the training of vocational ability as the goal of classroom teaching reform - to improve the effectiveness of business English core curriculum evaluation of satisfaction;

Michelsy 2017 Nanjing Institute of Vocational Technology graduates training quality tracking evaluation report Exposure of business English major Another problem is: graduates of professional core curriculum satisfaction rating of $77 \%$, see Figure VII. The evaluation there is still much room for improvement. Therefore, it is necessary for business English major of South Institute to carry out classroom teaching reform aimed at cultivating vocational ability, improve the effectiveness of classroom teaching and enhance students' satisfaction with professional courses. For example, in the process of teaching, we choose teaching materials which are closely linked with the working scene and teaching contents keep pace with the times. In the classroom, we use modern technical education to show our students the knowledge, abilities and skills they need to work in an intuitive manner. Assign assignments in the form of task assignments, assess learning outcomes in the form of performance appraisals, and evolve student learning processes into job internship processes.

As Chinese economy accelerates with the international economy, Business English professionals will get more opportunities than ever before. In order to improve the quality of business English professionals training in South Institute of Technology, improve the employment of graduates and professional relevance and graduates of professional curriculum evaluation satisfaction, at the same time, in order to further move closer to undergraduate education, Business English professional standards and "business English standard "For the construction of standards, combing personnel training objectives, to establish a reasonable system of professional courses, so as to develop a knowledgeable, capable and qualified business English professionals.

\section{Acknowledgement}

2015 Nanjing Institute of Industry and Technology High Education Research Institute Key Item: The research and Practice for the Combination of Courses Contents and Vocational Standard of 
Business English Major (GJ15-05Z)

2015 The Internationalization of Higher Vocational College Project: The Research for the Teaching Standard of Business English of Internationalization of Higher Vocational College (GJ2016-021)

\section{References}

[1] "Mycos" research on The Cultivation Quality of All the Graduates of Nanjing Institute of Industry and Technology 2015-2016

[2] Bargiela-Chiappini, F. 2013. In C. Nickerson \& B. Planken (eds.). Business Discourse (2nd ed.) [M]. Basingstoke: Palgrave Macmillan.

[3] Basturkmen, H. 2010. Developing Courses in English for Specific Purposes [M]. Basingstoke: Palgrave Macmillan.

[4] Ellis, M. \& O. Johnson. 2002. Teaching Business English [M]. Shanghai: Shanghai Foreign Language Education Press.

[5] Varner, Iris I.2 000.The theoretical foundation for intercultural business communication: A conceptual model [J]. Journal of Business Communication 